University of Louisville

ThinkIR: The University of Louisville's Institutional Repository

Faculty Scholarship

Fall 2016

Rhetoric and performing anger : Proserpina's gift and Chaucer's

Merchant's tale.

Joseph Turner

University of Louisville

Follow this and additional works at: https://ir.library.louisville.edu/faculty

Part of the English Language and Literature Commons, Performance Studies Commons, and the Rhetoric Commons

Original Publication Information

Turner, Joseph. "Rhetoric and Performing Anger: Proserpina's Gift and Chaucer's Merchant's Tale." 2016. Rhetorica: A Journal of the History of Rhetoric, 34(4): 427-454.

This Article is brought to you for free and open access by ThinkIR: The University of Louisville's Institutional Repository. It has been accepted for inclusion in Faculty Scholarship by an authorized administrator of ThinkIR: The University of Louisville's Institutional Repository. For more information, please contact thinkir@louisville.edu. 


\title{
JOSEPH TURNER
}

\section{Rhetoric and Performing Anger: Proserpina's Gift and Chaucer's Merchant's Tale}

\begin{abstract}
Although scholars have historically minimized the relationship between medieval grammatical and rhetorical traditions and Chaucer's poetics, Proserpina's angry speech in the Merchant's Tale represents the intersection of medieval classroom grammar exercises, Geoffrey of Vinsauf's theory of delivery, and poetics. Proserpina's angry speech reveals that her rhetoric is calculated to subvert the masculine power structures that surround her. Such a focus on Chaucer's depiction of women's persuasive tactics helps to highlight Chaucer's deep engagement with rhetoric beginning in the 1380's. Moreover, this investigation asks for increased attention to the overlap between classroom grammatical traditions, rhetorical theory, and medieval poetics.
\end{abstract}

Keywords: Performance, Grammar, Geoffrey of Vinsauf, Chaucer, Poetics, Anger, Claudian, Progymnasmata

"Anger, child of fire and mother of fury, springing up from the very bellows, poisons the heart and soul. It stings with its bellows, sears with its fire, convulses with its fury. Under its emotion, a caustic voice speaks." Geoffrey of Vinsauf, Poetria Nova ${ }^{1}$

"Ye shal? ... . wol ye so?

Now by my moodres sires soule I swere,

${ }^{1}$ Geoffrey of Vinsauf, ed. Edmond Faral, Les arts poétiques du xiie et du xiiie siècle (Paris, Champion, 1923), 2041-44, 260. "Ira, genus flammae materque furoris, ab ipso / Folle trahens ortum, cor et interiora venenat; / Pungit folle, cremat flamma, turbatque furore, / Exit in hac ipsa forma vox fellea." Translated Margaret F. Nims (Toronto: Pontifical Institute of Mediaeval Studies, 1967), 79.

Rhetorica, Vol. XXXIV, Issue 4, pp. 427-454. ISSN: 0734-8584, electronic ISSN: 1533-8541. (c) 2016 by The International Society for the History of Rhetoric. All rights reserved. Please direct all requests for permission to photocopy or reproduce article content through the University of California Press's Reprints and Permissions web page, http://www.ucpress.edu/journals.php?p=reprints. DOI: 10.1525/rh.2016.34.4.427. 
That I shal yeven hire suffisant answere,

And alle wommen after, for hir sake,

That, though they be in any gilt ytake,

With face boold they shulle hemself excuse,

And bere hem doun that wolden hem accuse." Proserpina ${ }^{2}$

$\mathrm{T}$

he Merchant's Tale, a bawdy fabliau of Chaucer's Canterbury Tales, follows most stock characteristics of the genre: adultery, trickery, and flouting authority. The dual plot structure of this comic tale tracks two intertwining narratives, both concerning domestic strife, violence, and power dynamics within marriage. In the primary, terrestrial portion of the tale, May, the young wife of the aged and blind knight January, enters into an adulterous affair with Damian, January's young squire. In the tale's secondary plot, Pluto and Proserpina watch and critique this trio's exploits from a heavenly vantage point. May's infidelity inspires a domestic argument between Pluto and Proserpina, and May's adultery becomes the central issue over which Pluto and Proserpina vie for power: Pluto wants to restore January's sight and to punish May, and Proserpina wishes to protect May from January's retribution. Inspired by Pluto's violence in the mythical rape of Proserpina, the goddess seeks to shield May, and other women, from the type of violence she suffers at Pluto's hands. Proserpina reveals this gift of defensive rhetoric in an angry tirade that, in the words of the medieval rhetorician Geoffrey of Vinsauf, "sears with its fire." She defiantly responds "Ye shal? . . wol ye so?" and, invoking a lineage of women who have come before her, bestows upon all women a gift of rhetoric that will protect them from masculine violence. Her anger becomes the means through which she combats Pluto's misogyny. "Proserpina's Gift" of rhetoric, which she grants to "alle wommen," ${ }^{3}$ helps May to assert agency within her relationship. Proserpina's gift also has implications for men and women beyond the Merchant's Tale: her gift articulates a theory of rhetoric that, throughout the Canterbury Tales, would help balance gendered power dynamics within marriage and help defend women from violence committed against them by men.

In addition to positing a theory of defensive rhetoric that helps to insulate women from masculine aggression, Proserpina's angry rhetoric marks a point of intersection between two lines of scholarly inquiry

${ }^{2}$ All Chaucer quotations are drawn from The Riverside Chaucer, 3rd ed., ed. Larry Benson (Boston: Houghton Mifflin, 1987) and are indicated by fragment, line, and page numbers. 4.2264-70, 166.

${ }^{3} \mathrm{Ibid}, 4.2267,166$. 
into medieval rhetorical theory. Nicolas Orme has traced "the vitality" of medieval grammar schools through the diffusion of rhetorical terminology in the works of Chaucer's contemporaries, ${ }^{4}$ and Orme has outlined Chaucer's debt to grammar schools in the Nun's Priest's Tale. ${ }^{5}$ Like Orme, Marjorie Curry Woods investigates Chaucer's debt to classical and medieval grammar and rhetoric, and she argues for a relationship between Chaucer's female characters and medieval educational traditions in which medieval boys composed and performed speeches in the voices of female characters. ${ }^{6}$ This tradition, a Latin tradition similar to the Greek progymnasmata, included individual exercises in imitation and performance, or what the Greeks called ethopoeia. ${ }^{7}$ In these exercises, students composed and performed speeches imitating characters from literary texts, which included composing and performing as women. Perhaps surprisingly, medieval boys in the grammar classroom wrote and performed speeches imitating women "in distress," including women who had been emotionally, physically, and sexually assaulted. ${ }^{8}$ R. T. Lenaghan and Peter Travis, like Woods, suggest Chaucer's familiarity with the progymnasmata tradition as it survived in the Latin west, exploring Chaucer's construction of fabula through medieval grammatical theory. 9

Woods' work intersects with Martin Camargo's examination of manuscript evidence that suggests increased production of Geoffrey of Vinsauf's Poetria Nova in the 1380's, which, Camargo argues, helped to transform Chaucer's "awareness of and attitude toward rhetoric as a discipline and continued to have an impact on his poetry for the

\footnotetext{
${ }^{4}$ Nicholas Orme, Medieval Schools (New Haven: Yale U P, 2006), 106.

${ }^{5}$ Nicholas Orme, “Chaucer and Education," Chaucer Review 16.1 (Summer 1981): 38-59, 48-49.

${ }^{6}$ Marjorie Curry Woods, "Boys Will Be Women," in Speaking Images, ed. R. F. Yeager (Asheville: Pegasus P, 2001), 143-66, 146.

${ }^{7}$ Marjorie Curry Woods, "Rhetoric, Gender, and the Literary Arts: Classical Speeches in the Schoolroom," New Medieval Literatures 11 (2009), 113-32, 113-14. Manfred Kraus, in "Progymnasmata and Progymnasmatic Exercises in the Medieval Classroom," in The Classics in the Medieval and Renaissance Classrooms, ed. Juanita Feros Ruys, John O. Ward, and Melanie Heyworth (Turnhout: Brepols, 2013): 175-98, outlines the debate over the survival of the Greek tradition in the Latin West during the Middle Ages. He does not find any evidence that the rigidly defined Greek progymnasmata program survived in the Latin West; however, he does note that "there can be little doubt that compositional exercises similar in character and complexity to their precursors within the ancient progymnasmatic system were widely practiced in the Middle Ages" (189).

${ }^{8}$ Woods, "Boys," 145.

${ }^{9}$ R. T. Lenaghan, “The Nun's Priest's Fable," PMLA 78.4 (Sep., 1963): 300-307; Peter Travis, Disseminal Chaucer (Notre Dame: U of Notre Dame P, 2010), 60-74.
} 
remainder of his career."10 Of particular emphasis for Camargo is the influence of medieval rhetorical theory on Chaucer's understanding of delivery. ${ }^{11}$ In this vein, Proserpina of the Merchant's Tale highlights the historical relationship between Chaucer's depiction of women's speech, medieval grammatical instruction, and theories of delivery from the Poetria Nova. By highlighting this relationship, I also argue for increased attention to the influence of medieval rhetorical theory on the production of medieval poetry; that rhetoric's influence on poetics is not confined solely to the realm of style, but rather that rhetoric shapes Chaucer's poetics in fundamental ways.

Chaucer's debt to rhetorical theory has long been a subject of debate, and critics have historically minimized the impact of medieval rhetorical texts and grammatical instruction on Chaucer's poetry. Camargo traces the terms of the debate to J. M. Manly's 1926 essay "Chaucer and the Rhetoricians," 12 in which Manly argues that Chaucer drew some stylistic figures from the arts of poetry and prose (artes poetriae) written by Geoffrey of Vinsauf, Matthew of Vendome, and Gervais of Melkley. However, Manly insists that Chaucer's mature work (and his comic works) demonstrate "a gradual release" from rhetorical theory, a release in which Chaucer replaces rhetorical theory with lived experience and influence from continental poets. ${ }^{13}$ Chaucer knew the work of Geoffrey of Vinsauf, Manly insists, but he gradually left rhetoric behind. James Murphy, in 1956, questioned Manly's assumption that Chaucer knew the artes poetriae at all in his "A New Look at Chaucer and the Rhetoricians." He dismisses Chaucer's debt to formal rhetorical textbooks such as the Poetria Nova, and he questions any potential relationship between such rhetorical texts and Chaucer's poetry by noting that "there is very little evidence of an active rhetorical tradition in fourteenth-century England."14 According to Murphy, Chaucer could have easily encountered sections of the Poetria Nova, such as the famous lament for Richard, ${ }^{15}$ in manuscripts that excerpted Geoffrey of Vinsauf's work, or that Chaucer may have learned rhetorical figures from common grammar

\footnotetext{
${ }^{10}$ Martin Camargo, "Chaucer and the Oxford Renaissance of Anglo-Latin Rhetoric," Studies in the Age of Chaucer 34 (2012): 173-207, 177.

${ }^{11}$ Ibid, 194.

${ }^{12} \mathrm{Ibid}, 173$.

${ }^{13}$ J. M. Manly, "Chaucer and the Rhetoricians," Warton Lecture on English Poetry $17,1-19,3$.

${ }^{14}$ James Jerome Murphy, "A New Look at Chaucer and the Rhetoricians." RES $\mathrm{n}$. s. 15 (1964): 1-20, 2.

${ }^{15}$ Poetria Nova, 368-430.
} 
textbooks. ${ }^{16}$ For Manly and Murphy, Chaucer's poetics owe little to nothing to the artes poetriae and the rhetorical theory those medieval textbooks represent.

In this essay, I work from the intersection of Camargo's and Woods' work in order to add to the growing body of evidence for Chaucer's debt to rhetoric and, more broadly, for increased attention to the relationship between medieval rhetoric and poetic. ${ }^{17}$ To achieve these ends, this essay reads Chaucer's Merchant's Tale, and specifically Proserpina's angry speech against Pluto, within an educational tradition in which medieval boys learned to compose as women in distressed situations and through Geoffrey of Vinsauf's advice on delivery from the Poetria Nova. Properly understanding the angry rhetoric of Chaucer's female characters such as Proserpina requires re-contextualizing Chaucer's poetry through the medieval classroom and through those texts central to rhetorical learning in late medieval England. If these educational exercises supplied the raw material for Proserpina's speech, then the Poetria Nova provided the terms of its expression. Proserpina's speech would, in the words of Peter Travis, take Chaucer's audience "back to school and back to basics." ${ }^{\prime 18}$ In transforming Proserpina from the silent, pitiable figure of Claudian's Rape of Proserpina (De Raptu Proserpinae) into a wilful, vocal foil for Pluto's misogyny, the Merchant's Tale articulates a theory of women's rhetoric through which women insulate themselves from masculine aggression.

This essay builds its primary definition of rhetoric from Cicero's On Invention (De Inventione), another influential text widely available in the Middle Ages, ${ }^{19}$ as the ability "to speak in a manner suited to

\footnotetext{
${ }^{16}$ Murphy, “A New Look,” 13; 17-18.

${ }^{17}$ Paul E. Prill has similarly argued for the rhetorical roots of medieval poetics in "Rhetoric and Poetics in the Early Middle Ages," Rhetorica 5.2 (Spring 1987): 129-47. Gila Aloni has similarly highlighted Chaucer's debt to rhetoric in "Lucrece's 'myght': Rhetorical/sexual potency and potentiality in Geoffrey Chaucer's Legend of Lucrece," Rhetoric Society Quarterly 29.3 (June 1999): 31-42, and, albeit in the Renaissance, James Egan has also argued for increased attention to the overlap between rhetoric and poetic in his "Rhetoric and Poetic in Milton's Polemics of 1659-60," Rhetorica 31.1 (Winter 2013): 73-110.

${ }^{18}$ Peter Travis, "The Nun's Priest's Tale as Grammar School Primer," Studies in the Age of Chaucer 1 (1984): 81-91, 82.

${ }^{19}$ For the ubiquity of Cicero's On Invention, see George Kennedy, Classical Rhetoric and its Christian and Secular Tradition (Chapel Hill: U of North Carolina P, 1999), 220, as well as John O. Ward, "The Medieval and Early Renaissance Study of Cicero's De Inventione and the Rhetorica ad Herennium: Commentaries and Contexts," in The Rhetoric of Cicero in its Medieval and Early Renaissance Commentary Tradition, eds. Virginia Cox and John O. Ward (Boston: Brill, 2006): 3-69.
} 
persuade an audience . . . by speech. ${ }^{\prime 20}$ However, as Christine Mason Sutherland has observed, women's rhetoric cannot be confined solely to the public sphere of the Ciceronian tradition (or the realm of contentio), but rather also must include interpersonal and private persuasion (or sermo). ${ }^{21}$ In this focus on Proserpina's rhetoric, Chaucer reworks Claudian's De Raptu Proserpinae for new argumentative and aesthetic ends. Rita Copeland has argued for a rhetorical system of translation in the Middle Ages that, as part of the translatio studii tradition, aims to co-opt the "power" and "status" of the classical tradition for vernacular translation and poetic invention. ${ }^{22}$ The authors of the artes poetriae provide one possible model for such translation. Like authors of other artes poetriae, Geoffrey of Vinsauf transforms "invention into an exegetical act," using authoritative source texts to produce new raw poetic material. In so doing, the artes poetriae outline how to "achieve difference with the given text," ${ }^{\prime 23}$ creating opportunities to refashion classical texts for different contexts and applications. In like fashion, the Merchant's Tale diverges from Claudian, remastering aspects of the treatment of gendered power dynamics in the De Raptu Proserpinae in order to theorize how women use language to level gendered power differences and to protect themselves from violence in domestic situations. Such character development reflects Chaucer's broader engagement with rhetoric, and a focus on performance and delivery, as new copies of Geoffrey of Vinsauf's Poetria Nova, among other classical and medieval rhetorical texts, became increasingly available in England in the 1380's. ${ }^{24}$

\section{The Medieval Classroom}

Medieval grammar schools were designed to provide students with proficiency in speaking, reading, and writing Latin. At the most basic levels, grammar instruction involved teaching basic Latin reading and speech: spelling, pronunciation, and vocabulary (or ars recte 1.5.6, 15 .

${ }^{20}$ Cicero, De Inventione, trans. H.M. Hubell (Cambridge: Harvard UP, 2006),

${ }^{21}$ For an overview of sermo in the Middle Ages, see Christine Mason Sutherland, "Medieval and Renaissance Rhetorical Studies of Women," in The Sage Handbook of Rhetorical Studies, ed. Andrea Lunsford (Washington: Sage, 2009), 53-66, esp. 58-60.

${ }^{22}$ Rita Copeland, Rhetoric, Hermeneutics, and Translation in the Middle Ages (Cambridge: Cambridge U P, 1991), 106.

${ }^{23}$ Ibid, 166, 174.

${ }^{24}$ Martin Camargo, "Medieval Rhetoric Delivers: Or, Where Chaucer Learned to Act," New Medieval Literatures 9 (2007): 41-62; Camargo, “Oxford," 176-77. 
loquendi). At the advanced levels, students leaned to interpret poetry (ennarratio poetarum) and to write both poetry and prose. ${ }^{25}$ The difficulty of reconstructing Chaucer's grammar education arises from the lack of material record from medieval classroom practice. As a result, we have only glimpses into what Chaucer's childhood classroom looked like. Because medieval students typically wrote on wax tablets instead of paper, very little material record of their classroom work survives. ${ }^{26}$ Undoubtedly, grammar instruction at the highest levels focused on the production of written texts. But the relative expense of paper meant that Chaucer's education, like that of his classical and early medieval forebears, included much oral recitation and delivery in addition to written compositions. Woods has done much to document late-medieval grammatical instruction and the role of reading aloud and performance in the grammar classroom. In classical, early-medieval, and Renaissance classrooms, students composed character analyses and performed speeches imitating characters from literary texts. Such individual imitative exercises were part of a series of tasks in which students learned to compose and perform speeches of gradually increasing sophistication. ${ }^{27}$ Although few such medieval imitative exercises survive, Woods and Camargo suggest there is "growing evidence of a continuation of this practice during the Middle Ages." ${ }^{28}$

These imitative exercises typically focused on particularly emotionally evocative scenes, often of women in distressful situations. Augustine recollects such lessons, in which he "was forced to memorize

\footnotetext{
${ }^{25}$ Murphy, Rhetoric in the Middle Ages: A History of Rhetorical Theory from St. Augustine to the Renaissance (Berkeley: U of California P, 1974), 136-38. See also Nicholas Orme, English Schools in the Middle Ages (London: Metheun, 1973), 87, 100. For a recent look at the type of grammar school Chaucer likely attended, see Lynn Arner, Chaucer, Gower, and the Vernacular Rising: Poetry and the Problem of the Populace after 1381 (University Park: Pennsylvania State UP, 2013), 27-29.

${ }^{26}$ Martin Camargo and Marjorie Curry Woods, "Writing Instruction in Late Medieval Europe," in A Short History of Writing Instruction, $3^{\text {rd }}$ ed., ed. James J. Murphy (New York: Routeledge, 2012), 114-47, 115.

${ }^{27}$ Woods, "Rhetoric, Gender," 113-14.

${ }^{28}$ Camargo and Woods, 137; See also Woods, "Boys" 145. For an overview of the progymnasmata in the Greek tradition, see Christy Desmet, "Progymnasmata," in Classical Rhetoric and Rhetoricians, eds. Michelle Ballif and Michael G. Moran (Westport: Praeger, 2005), 296-304. For a more comprehensive treatment of the Greek tradition, see George Kennedy, Progymnasmata: Greek Textbooks of Prose Composition and Rhetoric (New York: Society of Biblical Literature, 2003). For a discussion of the progymnasmata and similar compositional exercises in the Latin Middle Ages, see Kraus, "Progymnasmata and the Progymnasmatic Exercises in the Medieval Classroom," particularly 191-92, cited in n. 7 above. For how the tradition developed in the Renaissance, see Lynn Enterline's Shakespeare's Schoolroom: Rhetoric, Discipline, Emotion (Philadelphia: U of Pennsylvania, 2012).
} 
the wanderings of some fellow called Aeneas ... and to weep over Dido." ${ }^{29}$ John of Salisbury, the $12^{\text {th }}$ century grammarian, reports that his teacher, Bernard of Chartres, also employed imitative exercises in this tradition. ${ }^{30}$ The practice continued from Augustine's Rome, through Bernard in the twelfth century, and well into the Renaissance. This tradition also found expression in neuming, or notating manuscripts for musical performance, in the early Middle Ages. ${ }^{31}$ Although the practice of neuming texts for in-class performance ceased around the beginning of the thirteenth century, manuscript evidence suggests that in the following centuries classical poetry and drama, and particularly the speeches of women, were marked out for nonmusical student performance. ${ }^{32}$ Jan Ziolkowski does not see the lack of surviving explicit references to imitative classroom practice as evidence of the tradition's decline. Rather, like Woods and Camargo, Ziolkowski argues that this lack of explicit reference perhaps "indicates that they were too commonplace to bear mentioning." ${ }^{\prime 33}$ In this tradition, the thirteenth century Hunterian v.8.14 manuscript, one of the few student texts that survives, preserves poems presumably written by male students on the emotions of mythical women such as Niobe, Arachne, and Io. ${ }^{34}$

Such grammar school experiences, in which students imitated and produced original compositions on the sufferings of historical and mythical women, grew from the thematic contents of texts used in grammar courses. The most common classroom anthology in Chaucer's England, the Liber Catonianus, or Cato Book, reflects the "favoured

${ }^{29}$ Augustine, trans. Maria Boulding, The Confessions (New York: New City Press, 1997), 1.13.20, 53.

${ }^{30}$ John of Salisbury, trans. Daniel D. McGrary, The Metalogicon of John of Salisbury (Los Angeles: U of California P, 1955), 1.24, 68.

${ }^{31}$ Jan M. Ziolkowski, Nota Bene: Reading Classics and Writing Melodies in the Early Middle Ages (Turnhout: Brepols, 2007), 153-72.

${ }^{32}$ Woods "Rhetoric, Gender," 116.

${ }^{33}$ Ziolkowski, 172.

${ }^{34}$ Harbert, Bruce, ed., A Thirteenth-Century Anthology of Rhetorical Poems (Toronto: Pontifical Institute of Mediaeval Studies, 1975). See also Marjorie Curry-Woods, "Performing Dido," in Public Declamations: Essays on Medieval Rhetoric, Education, and Letters in Honour of Martin Camargo (Turnhout: Brepols, 2015): 253-66, in which Woods argues that manuscript glosses expanded on the discussion of pronuntiatio (delivery) in an edition of the pseudo-Ciceronian Rhetorica ad Herennium to include instructions for classroom "performer[s] to convey appropriately the emotional effect of Dido's words" (254). Although the particular manuscript she investigates is later (c1469) and focuses on Dido, the classroom tradition these glosses represent can also illuminate how students might have performed other mythological women in Chaucer's time. 
auctores" of the Middle Ages. ${ }^{35}$ Included in that basic manual for grammar school instruction are, among others, Claudian's The Rape of Proserpina (De Raptu Proserpinae), Ovid's Heroides and Art of Love (Ars Amatoria), and Statius' Achilleid ${ }^{36}$ —all texts that Chaucer would have access to during his primary education. ${ }^{37}$ Several commentaries on Claudian's The Rape of Proserpina of English origin survive, ${ }^{38}$ and the commentary tradition suggests that the text was used to teach students in basic issues of Latin grammar: "It told a straightforward story in not too difficult Latin and was of a suitable length for a class text where pupils might not read very quickly." ${ }^{39}$ Geoffrey of Vitry, whose commentary on The Rape of Proserpina was widely imitated, indicates the text's educative potential: he uses Claudian's text to teach grammar to a wide variety of students and to sharpen their natural intelligence. ${ }^{40}$

\section{Rhetoric and Classroom Texts}

Woods argues that "sexual imagery is omnipresent in the texts used to teach Latin to medieval boys, and rape is a common narrative vehicle in these texts. ${ }^{41}$ Many of the texts that Chaucer would have encountered as a grammar student-Ovid, Claudian, and Statius-include vivid depictions of rape. Woods has demonstrated the pedagogical use of rape in Statius' Achilleid, for example, and how grammarians

\footnotetext{
${ }^{35}$ Hunt, Tony, Teaching and Learning Latin in Thirteenth-century England (Woodbridge, Suffolk: D.S. Brewer, 1991), 60.

${ }^{36}$ For a detailed account of the Liber Catonianus, see Tony Hunt, Teaching and Learning Latin in Thirteenth-century England, (Woodbridge, Suffolk: D.S. Brewer, 1991), 59-79. See also Robert A. Pratt, "Chaucer's Claudian," Speculum 22.3 (July, 1947), 419-29, 419-22. See also Orme, Medieval Schools, 98-100.

${ }^{37}$ Rickert, Edith, “Chaucer at School." Modern Philology 29.3 (Feb. 1932), 257-74, 257.

${ }^{38}$ Appendix A of Clarke and Giles' The Commentary of Geoffrey of Vitry on Claudian "De Raptu Proserpinae" discusses the manuscript tradition (122-24). See also F. Edward Cranz, ed., Catalogus Translationum et Commentariorum 3: Mediaeval and Renaissance Latin Translations and Commentaries (Washington: Catholic U of America, 1976), 161-71.

${ }^{39}$ Gaufridus, A. K. Clarke, and Gaufridus, The Commentary of Geoffrey of Vitry on Claudian "De Raptu Proserpinae" (Köln: Brill, 1973), 5.

${ }^{40}$ The Commentary of Geoffrey of Vitry, 24. "Intentio actoris est triplex, scilicet ingenii praeacutio et Florentini in aliquo satisfactio et eruditio auditorium."

${ }^{41}$ Marjorie Curry Woods, "Rape and the Pedagogical Rhetoric of Sexual Violence," in Criticism and Dissent in the Middle Ages, ed. Rita Copeland (New York: Cambridge U P, 1996), 56-86, 58.
} 
used that same work to model the parts of a classical oration. ${ }^{42}$ However, Chaucer's use of Claudian's The Rape of Proserpina, in the context of classroom imitative exercises on the sufferings of mythical women and Proserpina's angry speech, has been largely unexplored.

In order to execute these ethopoeia-like imitative exercises, students would necessarily have to submit female characters to character analyses. Successful execution of such exercises, Christy Desmet explains, "depends on the fledgling orator's ability to identify with others-that is, to put himself in the "place" of persons, real or imagined, who are remote from him in space and time." ${ }^{\prime 3}$ These character analyses grew from Cicero's discussion of the attributes of persons. Cicero, in his On Invention, discusses the attributes of persons in a judicial context. ${ }^{44}$ Woods argues that Chaucer adapted Cicero's system in constructing Criseyde's character and familial history in Troilus and Criseyde. ${ }^{45}$ Later rhetoricians, such as Geoffrey of Vinsauf and Matthew of Vendome, modified Cicero's system for writing poetry. Matthew describes the eleven personal attributes, including "Name, nature, style of life, fortune, quality, diligence, reaction, deliberation, chance events, deeds, speech." ${ }^{\prime 46}$ Geoffrey of Vinsauf describes the process of assigning "fitting" properties when composing: "the properties of persons and things which are described should be observed, and time ought to be spent on the assigning of those properties which are fittingly attributed to persons and things." Geoffrey lifts his examples from Horace's Ars Poetica, and he notes several examples of mythological women who have been wronged: "Let Medea be fierce and unconquered, Ino weeping, Ixion perfidious, Io wandering, Orestes sad." too, advises authors to consider an abbreviated list of the attributes of persons, including "sex, age, condition, event, place, or time." ${ }^{\prime 8}$ From imitative exercises and analyses of character, medieval grammar students learned to identify with and to impersonate female characters, many of whom suffered sexual assault.

Proserpina, in The Rape of Proserpina, experiences the kind of emotional distress on which medieval imitation exercises capitalized. In Claudian's text, Pluto abducts Proserpina while she gathers flowers

\footnotetext{
${ }^{42}$ Woods, "Rape"; "Rhetoric, Gender."

${ }^{43}$ Christy Desmet, "Progymnasmata," 301. Cited in n. 28 above.

${ }^{44}$ De Inventione, 1.34-36, 99-109; 2.32-34, 265-73.

${ }^{45}$ See "Chaucer the Rhetorician: Criseyde and her Family," The Chaucer Review 20.1 (Summer 1985): 28-39.

${ }^{46}$ Matthew of Vendome, trans. Roger P. Parr. Ars Versificatoria (Milwaukee: Marquette U P, 1981), 44.

${ }^{47}$ Documentum, 86.

${ }^{48}$ Poetria Nova, 82.
} 
with a company of nymphs. The raptus is figured more as abduction than nonconsensual intercourse, and the accessus to Geoffrey of Vitry's commentary, which outlines how the text was used in the classroom, similarly figures it as an abduction. ${ }^{49}$ However, Proserpina and the women around her understand that her virginity is at stake..$^{50}$ Pluto, the "fierce ravisher," is depicted as a lion feasting on the entrails of a mutilated cow (Gruzelier). ${ }^{51}$ Pluto's intrusion, which Claudian compares to a military ambush, destroys Proserpina's idyllic and innocent female community. ${ }^{52}$ Pallas Athena and Diana, out of a sense of feminine solidarity, attempt to defend Proserpina from Pluto. Diana, in particular, is compelled by "common maidenhood" to protect Proserpina. ${ }^{53}$ Despite this showing of feminine solidarity, Jupiter forbids the goddesses to fight against Pluto-and out of "respect for our father" ("reverentia patris") and fear of Jupiter's power ("imperio vinci maiore fatemur," Diana says), Pallas and Diana are forced to submit. ${ }^{54}$ Jupiter's intervention restricts any female resistance to Pluto's power. Proserpina laments her lack of agency in light of Pluto's and Jupiter's power:

O how fortunate were all the girls that other abductors have carried off! At least they enjoy the common light of day. But to me is denied both my virginity and the heavens, my chastity is stolen along with the light, and, leaving the earth behind me, I am led as a captive to serve the tyrant of Styx. ${ }^{55}$

The dual signification of raptus allows Claudian to imply nonconsensual intercourse under the guise of abduction. Although Proserpina is not physically raped, the bloody imagery of the abduction, and Proserpina's explicit reference to her stolen virginity, suggest that she understands the raptus as both abduction and non-consensual intercourse. To Proserpina, Pluto is the worst kind of tyrant: Pluto not only forces Proserpina to exchange her flower-filled and idyllic homeland

\footnotetext{
${ }^{49}$ Vitry, 23.

${ }^{50}$ Woods argues that the rape is figurative. See "Rape," 75, n. 41. Compare to Jill Mann's treatment in Feminizing Chaucer (Rochester: D.S. Brewer, 1991) in which she argues for a literal rape, 52-54.

${ }^{51}$ Claudian, trans. Claire Gruzelier. De Raptu Proserpinae (Oxford: Clarendon P, 1993), 2.209-13.

${ }^{52}$ Ibid, $2.163-70$.

${ }^{53} \mathrm{Ibid}, 2.207-08$.

${ }^{54} \mathrm{Ibid}, 2.228-36$.

${ }^{55} \mathrm{Ibid}, 2.260-64$. "o fortunatas alii quascumque tulere / raptores! saltem communi sole fruuntur. / sed mihi virginitas pariter caelumque negatur, / eripitur cum luce pudor, terrisque relictis / servitum Stygio ducor captiva tyrrano."
} 
for the bleakness of the underworld, but she knows that she must eventually lose her virginity to him as well. Rapist and tyrant though he is, Proserpina's lamentation inspires pity in Pluto. He attempts to soothe Proserpina and to alleviate her fears, and he promises her happiness as queen of the underworld. Whether or not Proserpina is swayed remains a mystery: she is silent during the rest of Book II, even during the wedding ceremony. Proserpina's silence, if speech represents a basic level of personal agency, emphasizes her forced submission to Pluto's and Jupiter's wills.

In the Merchant's Tale, Chaucer condenses Claudian's The Rape of Proserpina into an emotionally heightened abbreviation of four lines. In that abbreviation, Chaucer explicitly references Claudian's The Rape of Proserpina, which could, for both Chaucer and his male audience, recall memories of that classroom text and imitation exercises. Chaucer tells of

the queene Proserpyna,

Which that he [Pluto] ravysshed out of [Ethna]

Whil that she gadered floures in the mede In Claudyan ye may the stories rede,

How in his grisely carte he hire fette. ${ }^{56}$

Proserpina is "ravysshed" - with its implications for both abduction and non-consensual intercourse-from a pastoral and virginal meadow. Etymologically, "ravysshed" is to steal, seize, attack, or rape ${ }^{57}$ It is unsurprising that, in reworking Claudian during the late Middle Ages, Chaucer does not dwell on ravishment as sexual assault, despite its heavy implication. As Kathryn Gravdal has noted, the "standard definition" of the term raptus in the Middle Ages, a term related in legal literature to ravishment, "is marriage by abduction." 58 This narration of the rape of Proserpina focuses on Pluto's activity: he "ravysshed" her and "fette" her in his cart, while Proserpina engages in the comparably inactive (and completely innocent) activity of gathering flowers. As a staple of the Cato Book, Chaucer perhaps feels that the audience knows the tale well enough that he does not need to dwell on it. However, this abbreviated telling could also recall other grammar exercises of the type that survive in Hunterian v.8.14: amplifications (amplificatio) and abbreviations (brevitas) of the same story of a

\footnotetext{
${ }^{56}$ Merchant's Tale 4.2229-33, 166.

57" ravishen," verb, definitions 1 and 2. The Middle English Dictionary. The Middle English Dictionary, 2001.

${ }^{58}$ Kathryn Gravdal, Ravishing Maidens (Philadelphia: U of Pennsylvania P, 1991), 6.
} 
woman's suffering. ${ }^{59}$ Geoffrey of Vinsauf, in discussing abbreviation, counsels to "Let emphasis be spokesman, saying much in a few words," and he models this kind of condensing by relying on emotionally charged words to create emphasis so that the narrative "sticks in the memory better." 60 The result is "a powerful psychological experience." 61 Geoffrey's example in the Poetria Nova is an abbreviated version of the Snow Child story:

A husband, selling him whom the adulterous mother feigns begotten of snow, in turn feigns him melted by sun. Since his wife feigns her offspring begotten of snow, the husband sells him, and likewise feigns he was melted by sun. ${ }^{62}$

Geoffrey's abbreviation of the Snow Child story, like Chaucer's condensing of Claudian, emphasizes the emotionally charged and psychologically impactful portions of the narrative. Chaucer's juxtaposition of Proserpina's passive innocence with Pluto's violent activity works through abbreviation to emphasize Proserpina's suffering. Chaucer also resorts to such condensed vignettes in The Legend of Good Women and the Monk's Tale. ${ }^{63}$ Copeland also notes that such a reading strategy - or using an abbreviated version of a source text in order to invent new poetic material-is a hallmark of the Poetria Nova.

To amplify or abbreviate . . . are the techniques that underscore the mastery of exegetical procedure by disguising that procedure as a form of invention. These are the techniques of stylistic analysis that the grammarians of late antiquity and the exegetes of the Middle Ages took over from rhetorical theory and elevated to a role of primary importance ... and these are the techniques that Matthew of Vendome and Geoffrey of Vinsauf elevate to an even greater prominence by making them the very tools of rhetorical performance, of invention. ${ }^{64}$

This abbreviation of Claudian's narrative, as a kind of diegetic digression before returning to the mimetic narrative of the Merchant's Tale, introduces the complexities of Pluto's past with Proserpina and the

\footnotetext{
${ }^{59}$ I do not imply that Chaucer knows the poems in the Hunterian manuscript. Rather, that these poems represent common texts produced in such imitation exercises.

${ }^{60}$ Poetria Nova, 40; Documentum, 54.

${ }^{61}$ Camargo and Woods, p. 132.

${ }^{62}$ Poetria Nova, 733-36, 42. See, too, Geoffrey's use of the same example in Documentum de modo et Arte Dictandi et Versificandi, 54.

${ }^{63}$ See also Jane Baltzell's treatment of amplification and abbreviation in the Prioress's Tale, in "Rhetorical 'Amplification' and 'Abbreviation' and the Structure of Medieval Narrative," Pacific Coast Philology 2 (Apr. 1967), 32-39, 36-38.

${ }^{64}$ Rita Copeland, Rhetoric, Hermeneutics, and Translation, 174.
} 
power that Pluto holds over his wife. Digression, as Geoffrey of Vinsauf explains, allows the poet to amplify the salient portions of the narrative. ${ }^{65}$

Chaucer had long turned to the Proserpina myth to signify power imbalances and abusive relationships. Proserpina appears three times in his poetry: first in the House of Fame, then in Troilus and Criseyde, and finally in the Merchant's Tale. In the House of Fame (c1380) and in Troilus and Criseyde (c1385), Chaucer inherits the basic narrative pattern from Claudian: Proserpina is a pitiable figure, subjected to masculine violence and power, mute in her suffering. In both the House of Fame and Troilus and Criseyde, Chaucer's use of the Proserpina myth foregrounds Proserpina's harsh treatment by a powerful and misogynistic man. In both poems, Proserpina is associated with "pyne," a word that signifies "hell" and the "pain or injury resulting from punishment." 66 In The House of Fame, Chaucer references Proserpina's suffering when the narrator encounters Claudian's likeness that stands atop a pillar:
on a piler stood
Of soulfre, lyk as he were wood,
Daun Claudian, the sothe to telle,
That bar up al the fame of helle,
Of Pluto, and of Proserpyne,
That quene ys of the derke pyne. ${ }^{67}$

Befitting a poet known for memorializing the king and queen of the underworld, Claudian's likeness is made of sulfur. Claudian's statue symbolizes the poet's fame and also the ubiquity of The Rape of Proserpina in the Cato Book tradition. Through this likeness, the narrator conjures the physical darkness of Proserpina's environment and also the emotional bleakness of her suffering. Like the inanimate statue, Proserpina is silent, fixed, and static. Just as Claudian's image is attached immovably to the top of the pillar, so too is Proserpina physically imprisoned by Pluto in the underworld.

Similar to her depiction in the House of Fame, Proserpina is a pitiable figure in Troilus and Criseyde, a figure who is unable to change her situation. To Troilus, Proserpina stands for those who have been wronged by older, powerful men. Pluto has abducted and imprisoned Proserpina against her will, isolating Proserpina from her mother, the goddess Ceres. From Troilus' perspective, Criseyde has been similarly

\footnotetext{
${ }^{65}$ Poetria Nova, 527-28, 35.

66" pyne," noun 1, definitions 1a and 1b. The Middle English Dictionary. The Middle English Dictionary, 2001.

${ }^{67}$ House of Fame, 3.1506-12, 366.
} 
'abducted' and imprisoned against her will by an older man-her father, Calchas-who prevents Troilus from reuniting with Criseyde. Troilus imagines that Proserpina, because of her mythical history, will sympathize with the type of torment that results from unfair separation from loved ones. Troilus invokes Proserpina in his refusal to move past his love for Criseyde. He laments,

but down with Proserpyne,

Whan I am ded, I wol go wone in pyne,

And ther I wol eternaly compleyne

My wo, and how that twynned be we tweyne. ${ }^{68}$

Not only does Troilus imagine descending into the physical torment of hell to join Proserpina, but he also imagines hell as a sort of "mental suffering, anguish, misery" implied by even another definition of "pyne."69 For Troilus, hell is a location of physical and mental strife, and he invokes Proserpina as a figure sympathetic to the type of misery that he currently endures. Troilus will join Proserpina to "compleyne" about his unfair separation from Criseyde (fate "twynned" Troilus and Criseyde in "tweyne"), a separation that recalls Proserpina's mythical separation from her mother and homeland. Troilus conjures Proserpina as someone who would be sympathetic to his situation: someone with whom he could complain about the kind of hell that results from unfair treatment by powerful men who misuse women.

Whereas in the House of Fame and Troilus and Criseyde Proserpina invokes the silent sadness of lost innocence and confinement in hellish torment, by the time she appears in the Canterbury Tales, Proserpina is not just a woman held against her will in Hades. Instead, she is a woman who has been physically and emotionally assaulted, a symbol of female subjugation at the hands of powerful men-but a woman who uses her voice to fight against men and the power structures that privilege them. Gravdal argues that rape in French pastourelle "give[s] expression to conflicts between social classes ... [it] displaces class conflict onto a sexual axis." ${ }^{\prime 70}$ That displacement also manifests in the Merchant's Tale's refashioning of the pastoral rape of Proserpina, although less as class conflict than as a critique male power and female subjectivity in marriage. That is, unlike Proserpina's forced submission in Claudian's original, Chaucer's retelling foregrounds Proserpina's rhetorical agency - the political dimension of the Proserpina myth,

\footnotetext{
${ }^{68}$ Troilus and Criseyde, 4.473-76, 544.

69" "pyne," noun 1, 2b, The Middle English Dictionary. See n. 66 above.

${ }^{70}$ Gravdal, "Ravishing Maidens," p. 17. See n. 58 above.
} 
and its focus on the relationship between male social power and female speech and subjectivity, is central to Chaucer's use of the myth. ${ }^{71}$ Although Marta Powell Harley claims that Chaucer's use of the Proserpina myth "fails to transcend antifeminist clichés," Chaucer invokes Proserpina in order to criticize the masculine power structures that enable unjust treatment of women. ${ }^{72}$ That is, Proserpina's angry speech both theorizes and enacts a model of defensive rhetoric that characterizes women's speech throughout the Canterbury Tales.

\section{Proserpina's Gift}

The archetypal nature of Pluto's argument with Proserpina has ramifications for men and women as a whole-Pluto wishes to extend men's power, and Proserpina wants to insulate women from men's authority. When Pluto threatens to expose May's infidelity "Bothe in repreve of hire and othere mo," or to shame and censure May along with any other unfaithful women, Proserpina responds with a gift of persuasion that both argues and enacts the kind of rhetorical action she gifts to May-and, by extension, to other women:

'Ye shal?' quod Proserpyne, 'wol ye so?'

Now by my moodres sires soule I swere

That I shal yeven hire suffisant answere,

And alle women after, for hir sake,

That, though they be in any gilt ytake,

With face boold they shulle hemself excuse,

And bere hem doun that wolden hem accuse.

For lak of answere noon of hem [women] shal dyen.

$\mathrm{Al}$ hadde man seyn a thyng with bothe his yen,

Yit shul we wommen visage it hardily,

And wepe, and swere, and chyde subtilly,

So that ye men shul ben as lewed as gees. ${ }^{73}$

Proserpina's defiant opening — “Ye shal? . . . wol ye so?" — explicitly questions Pluto's authority and recollects for the Canterbury Tales reader such combative wiles as those of the Wife of Bath. Proserpina's

${ }^{71}$ For more on Chaucer's consistent depiction of women's rhetoric as positive, see David Raybin, "The Death of a Silent Woman: Voice and Power in Chaucer's Manciple's Tale," Journal of English and German Philology 95.1 (1996): 19-37.

${ }^{72}$ Marta Powell Hartley, "Chaucer's Use of the Proserpina Myth in 'The Knight's Tale' and 'The Merchant's Tale,'" in Images of Proserpina, ed. Elizabeth T. Hayes (Miami: U of Florida P, 1994), 20-31, 21.

${ }^{73}$ Merchant's Tale, 4.2263-75, 166. 
defiance leads her to bestow on women the gift of persuasive speech: restore January's sight, she seems to threaten, and see what happens. The major use of Proserpina's defensive rhetoric is to protect women from violence committed against them by men. According to Proserpina, women will always have tactics to ensure that none of them will die as a result of men's questioning - and women will have an arsenal of such persuasive maneuvers, such as weeping, chiding, and lying, to keep men "as lewed as gees," or as clueless as birds.

Proserpina's speech is doubly performative: Chaucer would have performed it aloud for his audience, and Proserpina's anger performs a theory of persuasion that she gives to all women. Andrew Taylor suggests that late medieval poetry was frequently performed aloud, and Joyce Coleman argues that Chaucer not only wrote for a "community of hearers," but that he also "anticipated a posterity of literate listeners." ${ }^{\prime 74}$ Paul Strohm argues that Canterbury Tales were historically read and performed aloud, to largely male audiences of fellow courtiers and chamber knights. ${ }^{75}$ Other scholars suggest broader, more socially diverse audiences that likely included women. ${ }^{76}$ Lynn Arner, however, argues that a variety of readers or listeners, many outside the chamber knights that Strohm describes, could have encountered Chaucer's works through reading of listening: "the literate auditors and/or solitary readers of ... Chaucerian poetry frequently included men and women from the upper strata of nonruling urban classes." Arner continues, citing growing literacy rates and the wide circulation of Chaucer's works in the late fourteenth century, that "Hearing the poetry of Gower or Chaucer would not have been an exceptional, fortunate event." ${ }^{\prime 77}$ Arner's and Strohm's work suggests that many middle and upper class medieval men and women would have had access to oral recitations, and sometimes to private readings, of

\footnotetext{
${ }^{74}$ Andrew Taylor, "Into His Secret Chamber: Reading and Privacy in Late Medieval England," in The Practice and Representation of Reading in England, ed. James Raven et al. (New York: Cambridge U P, 1996), 41-61 (pgs. 41-43); Joyce Coleman, Public Reading and the Reading Public in Late Medieval England and France (New York: Cambridge U P, 1996), 178; 148. Paul Strohm forwards a similar argument in Social Chaucer (Cambridge, MA: Harvard UP, 1989), 47.

${ }^{75}$ Strohm, Paul. Social Chaucer (Cambridge, MA: Harvard UP, 1989), 41-46.

${ }^{76}$ In addition to Strohm, for Chaucer's audience as chamber knights, see Horvath, Richard P. "Chaucer's Epistolary Poetic: The Envoys to Bukton and Scogan." Chaucer Review 37.2 (2002): 173-89, 173-75. For women in Chaucer's audience, see Lynn Arner, 18, 34, 44 (see n. 25 above) and Richard Firth Green, "Women in Chaucer's Audience," The Chaucer Review 18.2 (Fall 1983): 146-54.

${ }^{77}$ Lynn Arner, Chaucer, Gower, and the Vernacular Rising, 44. See the chapter titled "Early Readership Expanded" for a comprehensive revisiting of Strohm's influence on scholarly perceptions of Chaucer's audiences.
} 
Chaucer's poetry. Such claims may broaden Coleman's "community of hearers" to "communities of hearers," opening opportunities to examine the effects of Proserpina's gift of rhetoric on both male and female audiences. To further establish the wide audience of Chaucer's works, scholars have demonstrated that Chaucer's epistolary poems addressed to historical contemporaries, such as the "L'envoy de Chaucer a Bukton," were intended for audiences beyond the addressee. ${ }^{78}$ The very format of the Canterbury pilgrimage-in which each pilgrim tells tales as part of a game-reproduces the role that orality and performance played in shaping the production and dissemination of Chaucer's poetry. $^{79}$

The public reading of Proserpina's speech, as a performance of anger in the tradition of grammar school imitation exercises, also grows from the "outrage and rebuke" that Martin Camargo argues characterizes Geoffrey of Vinsauf's focus on delivery and performance in the Poetria Nova. ${ }^{80}$ Geoffrey dedicates roughly half of his discussion of delivery to the performance of anger:

Anger, child of fire and mother of fury, springing up from the very bellows, poisons the heart and soul. It stings with its bellows, sears with its fire, convulses with its fury. Under its emotion, a caustic voice speaks; an inflamed countenance and turbulent gestures accompany it. The outward emotion corresponds with the inward ... If you act the part of this man, what, as reciter, will you do? Imitate genuine fury, but do not be furious. Be affected in part as he is, but not deeply so. Let your manner be the same in every respect, but not so extreme; yet suggest, as is fitting, the emotion itself. ${ }^{81}$

\footnotetext{
${ }^{78}$ See Jane Chance, "Chaucerian Irony in the Verse Epistles 'Wordes Unto Adam,' 'Lenvoy a Scogan,' and 'Lenvoy a Bukton,'" Papers on Language and Literature 21.2 (Spring 1985): 115-128.

${ }^{79}$ For more on Chaucer's storytelling, and the debt of the tale structure to medieval rhetorical understandings of circumstantiae, see Glending Olson, "Rhetorical Circumstances and the Canterbury Storytelling," Studies in the Age of Chaucer 1 (1984): 211-18. Leonard Michael Koff also emphasizes the role of performance in the Merchant's Tale in his Chaucer and the Art of Storytelling (Berkeley: U of California, 1988), 110-117.

${ }^{80}$ Camargo, "Medieval Rhetoric Delivers," 55.

${ }^{81}$ "Ira, genus flammae materque furoris, ab ipso / Folle trahens ortum, cor et interiora venenat; / Pungit folle, cremat flamma, turbatque furore, / Exit in hac ipsa forma vox fellea, vultus / Accensus, gestus turbatus; et interiorem / Exterior sequitur motus ... Personam si geris ejus, / Quid recitator ages? Veros imitare furores. / Non tamen esto furens: partim movearis ut ille, / Non penitus; motusque tuus sit in omnibus idem, / Non tantus; sed rem, sicut decet, innue," 2041-51, 260. Nims, 78-79.
} 
Proserpina's angry speech raises the question of emotional veracity that Geoffrey of Vinsauf explores. On one hand, she is the rightfully angry victim of sexual assault, and it is easy to imagine Proserpina's "caustic voice" and "turbulent gestures," or how a performer might imitate them. On the other hand, her speech is rhetorically calculated to take power from her husband. Geoffrey of Vinsauf's distinction between inward and outward anger recalls medieval theories of the passions of the soul, which theorized that outward anger is accompanied by predictable somatic effects. Thomas Aquinas, for example, describes anger as "a fervor in the blood and vital spirits around the heart, the instrument of the emotions. Another effect of the marked disturbance of the heart . . . is the signs in the external members of those who are angry." ${ }^{\prime 82}$ Proserpina's bold face, her swearing and weeping, are outward manifestations of her anger. Moreover, she later tells Pluto that she will "swelle til myn herte breke," a reference to the physical changes to the heart that accompany anger. These symptoms can be read, following Geoffrey of Vinsauf, either as genuine anger or a means of constructing verisimilitude. Kristi Gourlay notes that female anger, especially in response to "perceived wrongs or insults, particularly insults that called the woman's sexual honor into question" often took a verbal, rather than physical, form in medieval legal and historical records. ${ }^{83}$ Proserpina, of course, has not been unfaithful to Pluto, and her angry speech at Pluto's callous slander would seem justified. Richard Barton observes that "properly zealous anger" could have rhetorical purposes when used by aristocrats, such as Pluto, the "kyng of Fayerye" and "his wyf, the queene Proserpyna." ${ }^{84}$ Such anger, according to Barton, "could serve as a sign that social relationships would have to be renegotiated, preferably by peaceful means." 85

\footnotetext{
${ }^{82}$ Thomas Aquinas, trans. John Patrick Reid, Summa Theologiae, vol. 21 (New York and London: Blackfriars, 1963): 1a2ae, Q48, 128-129. "consequenter fit motus irae causativus cujusdam fervoris sanguinis et spirituum circa cor, quod est instrumentum passionum animae. Et exinde est quod, propter magnam perturbationem cordis quae est in ira, maxime apparent in iratis indicia quaedam in exteriorbus membris."

${ }^{83}$ Kristi Gourlay, "A Pugnacious Pagan Princess: Aggressive Female Anger and Violence in Fierabras," in The Representation of Women's Emotions in Medieval and Early Modern Culture, ed. Lisa Perfetti (Gainesville: U of Florida P, 2005): 133-163, 139-140. Gourlay also notes that angry women in literature, as opposed to historical ones, are "generally punished or reprimanded." Proserpina, like Floripa of Fierabras (which her article investigates), would seem to be an exception to this rule.

${ }^{84}$ Merchant's Tale, 4.2227-29.

${ }^{85}$ Richard E. Barton, "'Zealous Anger' and Aristocratic Relationships," in Anger's Past: The Social Uses of an Emotion in the Middle Ages, ed. Barbara H. Rosenwein (Ithaca and London: Cornell U P, 1998): 153-170, 155. Barton's observations are focused on
} 
Despite her personal anger-or, indeed, because of it-Proserpina's angry rhetoric has a political agenda that implicates all women and men: although Pluto wants to extend men's power, she wants to check it. There is a performative aspect to her anger, in that she understands the impact such a caustic voice will have on her husband. She does not allow her legitimate anger to thwart her rhetorical purpose: she will not allow other women such as May to be victimized in the ways that she has. In that way, her personal anger does not hinder her ability to monopolize the somatic signifiers of anger for calculated rhetorical purposes.

Proserpina's speech becomes an angry tirade against Pluto and the misogynist traditions that he represents-against what David Aers calls "male moralisation." ${ }^{\prime 86}$ Just as the Merchant's Tale does not dwell on the rape, so too does Geoffrey of Vitry's commentary on The Rape of Proserpina pass over it as well-instead, the commentary offers elementary explanations of plot and grammar. But in passing over the rape, the Merchant's Tale instead emphasizes Proserpina's anger as a tactic that works to preclude other women from being abused and subjugated by men such as Pluto or January. ${ }^{87}$ She brings the discussion, in other words, out of the realm of myth and into the world of the domestic. Proserpina utilizes her anger to press Pluto into submission, until he exclaims "I yeve it up!," 88 enacting a chiding rhetoric that helps to subvert the power differential between Pluto and Proserpina, between women and men. Such a performance of anger reveals a surprising consistency of the rhetorical function of anger in rhetorical education and culture, resonating with the youthful classroom experiences of male audience members. At the same time, Proserpina's speech also suggests that the defensive rhetoric Proserpina theorizes and enacts is, in fact, logically calculated to check the power of predatory men such as Pluto and to satirize traditions that support misogynistic behavior.

In addition to vindicating her individual actions, Pluto's treatment of Proserpina highlights the more general power that men held over women. Pluto's authority over Proserpina stems from both his godhood and the fact that, as he says, "I am a kyng," which in Chaucer

men; however, the political import of anger has implications for Pluto's and Proserpina's domestic argument.

${ }^{86}$ David Aers, Chaucer (Brighton: Harvester P, 1986), 74.

${ }^{87}$ Although Lynn Enterline is focused on Shakesepare, her observations on Renaissance Latin grammar training resonate with Chaucer's focus on women's angry rhetorical tactics: "[Shakespeare] has a pronounced tendency to interrogate the grammar school's language, curriculum, and disciplinary methods for achieving eloquence by giving a voice to the emotions of precisely those whom its rhetorical training was designed to exclude: women," 24 , cited in n. 28 above.

${ }^{88}$ Merchant's Tale, 4.2312, 167. 
as in Claudian equate to social and physical authority. ${ }^{89}$ But unlike the Pluto from Chaucer's source material, who (although his crime is nonetheless monstrous) feels sympathy for Proserpina and attempts to alleviate her fears, Pluto of the Merchant's Tale resorts to misogynist discourse in order to justify his behavior. If possible, Chaucer's Pluto is more of a misogynist than Claudian's: instead of Claudian's repentant Pluto, Chaucer's Pluto is aggressively antifeminist. Although the Pluto of Claudian expresses remorse for his actions, Chaucer's depiction of the rapist Pluto can be illuminated through comparison with another rapist from the Cato Book tradition, the unrepentant Pamphilus. ${ }^{90}$ Pamphilus considers raping Galatea as "a mere trifle," and he says that "Her anger is far greater than I deserve." To him, Gatatea's anger is only a "lovers' quarrel." ${ }^{\text {91 }}$ Chaucer's Pluto is similarly unrepentant, and the Merchant's Tale fashions the exchange between Proserpina and Pluto as a type of lovers' quarrel, replacing Galatea's anxiety over her loss of social mobility with Proserpina's anger. By resorting to misogynist discourse and his social and legal authority, Pluto attempts to manage his wife and her behavior.

Proserpina's responses to Pluto's misogyny foreground the role of angry speech in leveling the playing field between men and women. Men such as Pluto might accuse women of angry chiding speech, but such speech is effective in combating the power that men hold over women. Pluto can restore January's sight and expose May's adultery, but Proserpina's rhetorical tactics ensure that men will remain as clueless as birds. Chaucer develops the emphasis on gendered power differentials inherited from Claudian by highlighting Proserpina's conflict with Pluto and with the misogynist tradition through which Pluto frames his attack on women. Pluto turns to misogynist discourse, and in particular to Solomon and Jesus of Sirach, who "knoweth youre wikkedneese." ${ }^{\prime 92}$ Pluto conflates Proserpina with all women into a cohesive group defined by sinful behavior; Proserpina is at once a single woman and all women. Not only does Proserpina endure rape and physical imprisonment at the hands of a powerful stranger, but Pluto immediately subjects her to misogynist taunts. The narrative proximity between the fabled rape and Pluto's misogyny

\footnotetext{
${ }^{89}$ Ibid, 4.2315, 167.

${ }^{90}$ Allison Goddard Elliott, trans., Seven Medieval Latin Comedies, vol. 20, series B (New York: Garland, 1984), 697-780. For the prevalence of Pamphilus in the medieval tradition, see Priscilla Bawcutt, "'Pamphilus de amore' 'in Inglish Toung,'"Medium Aevum 64:2 (1995): 264-72.

${ }^{91}$ Pamphilus, 751-55.

${ }^{92}$ Merchant's Tale, 4.2249, 166.
} 
is surprising: directly after the narration of the Rape of Proserpina, Pluto "right anon," or right away, begins an antifeminist tirade impugning the character of Proserpina and all women.

Th'experience so preveth every day

The tresons whiche that wommen doon to man.

Ten hondred thousand [tales] tellen I kan

Notable of youre untrouthe and brotilnesse. ${ }^{93}$

As Jill Mann so eloquently summarizes, "This is a rapist talking." 94 Moments earlier, Proserpina was gathering flowers with other maidens. However, Pluto frames the indiscretions and treasons of other women as "youre," or Proserpina's, fickleness and lack of fidelity. Mann characterizes Proserpina's angry response to Pluto's misogyny as a type of "female shrewishness [that] is both the inevitable response to male aggression and its proper punishment." ${ }^{\prime 95}$ Although Proserpina's angry rhetorical tactics may be calculated to punish her misogynist husband, as Mann suggests, those same tactics also point to a system of social inequity that Proserpina's rhetorical tactics help to subvert. Proserpina's innocence, coupled with the narrative proximity of Pluto's taunts to the mythical rape, suggest that Pluto is powerful, unfair, callous, and predatory-he is a man equipped with strategies that enable him to leverage power against women. A woman such as Prosperina, then, would seem vindicated to use whatever tools are at her disposal, and her rhetorical tactics seem more concerned with leveling gendered power differentials than with punishment.

Although May is not raped, there are sufficient parallels between Proserpina's and May's histories with powerful men to liken their positions. For one, there is the testimony of Pluto himself: all women are the same, according to the God of the Underworld, and by extension so are their social conditions. Further, just as Prosperina was "taken" without her consent, so too does May endure her marriage in silence. That is, before the wedding, January debates the virtues of marriage with Placebo, who urges him to marry, and Justinus, who urges him not to. No such debate occurs for May; any thoughts or desires she has about marriage are absent from the text. ${ }^{96}$ Just as she is unable to vocalize her thoughts on marriage, May keeps her displeasure at the consummation of her marriage quiet: only "God woot what

${ }^{93}$ Ibid, 4.2235-41, 166.

${ }^{94}$ Jill Mann, 52 (emphasis original). See n. 50 above.

${ }^{95}$ Ibid, 54.

${ }^{96}$ Charles Muscatine, Chaucer and the French Tradition (Los Angeles: U of California P, 1957), 233. 
that May thoughte in hir herte ... She preyseth nat his pleyyng worth a bene." ${ }^{\prime 97}$ The explicit comparison between January's aged body and May's youthful body, and the lack of pleasure May receives on her wedding night, suggest that May's marriage is inequitable. May is, like Proserpina, taken from her innocent and virginal state by a socially powerful man, and January's marriage to May recalls the power differential between Pluto and Proserpina. May's unhappiness and the inequity of her marriage compel her toward a lustful affair with Damian, January's young squire. Just as in Proserpina's abduction by Pluto, May is silent when she is married to January, and this absence of speech indicates a lack of agency. Thus, comparing Proserpina's abduction with May's marriage emphasizes that, while men might criticize women for launching a rhetoric of harangue, flattery and lies, it would seem the only rhetoric of a "good" woman is silence. ${ }^{98}$

In addition to rejecting this silence and recognizing speech as central to personal agency, Proserpina also recognizes misogynist discourse as the means through which men derive power over women. In contrast to Claudian's powerless and silent Proserpina, Chaucer's Proserpina sees speech, and in particular chiding speech, as the rhetorical tactic through which to transgress Pluto's masculine authority. In response to Pluto's use of Solomon to support his misogyny, Proserpina says:

What make ye so muche of Solomon? ...

Pardee, as faire as ye his name emplastre,

He was a lecchour and an ydolastre...

I sette right noght, of al the vileynye,

That ye of wommen write, a boterflye!

I am a womman, nedes moot I speke,

Or ells swelle til myn herte breke.

For sithen he seyde that we been jangleresses,

As evere hool I moote brouke my tresses,

I shal nat spare, for no curteisye,

To speke hym harm that wolde us vileynye. ${ }^{99}$

In the most obvious deviation from Claudian, Proserpina here develops her mission of protecting women from masculine violence. Instead of the powerless goddesses of Claudian, Chaucer's Proserpina

${ }^{97}$ Merchant's Tale, 4.1851-54, 161.

${ }^{98}$ As David Raybin argues, women in the Canterbury Tales use speech to avoid punishment from men, cited in $\mathrm{n}$. 71 above. I do not mean silence as an intentional rhetorical tactic of the type that Cheryl Glenn develops in Unspoken: a Rhetoric of Silence (Carbondale: Southern Illinois UP, 2004).

${ }^{99}$ Merchant's Tale, 4.2292-2310, 166-67. 
is strong, vocal, and sees speech as the means through which to check men's power. For as long as she lives, Proserpina will speak against any man who would disparage women. Proserpina's simile grounds her protective capacity in a feminine symbol: as long as "I moote brouke my tresses," a colorful way of saying "for as long as I live," but literally "for as long as I enjoy my tresses of hair," she will speak out against misogynists. ${ }^{100}$ Moreover, her femininity-not her divinity-is the reason that she must speak: "I am a woman, nedes moot I speke." Socially powerful men, such as Pluto or Solomon, depict women as "jangleresses," or chatterboxes, but Proserpina targets her speech at men who would do villainy to women. Such speech may be transgressive, but it seems to be effective: after this tongue lashing, Pluto exclaims, "I yeve it up!" and the argument ends. ${ }^{101}$ And, although Pluto restores January's sight, Proserpina's gift of persuasion allows May to keep her infidelity secret-like Prosperina, May's words win in the end. That is, January does catch May and Damian together, but May, using the tactics she learns from Proserpina, convinces January that he is still half blind: she is merely wrestling with Damian in a tree. Although January questions May's account, saying that Damian "swyved thee," May is able to convince him that her account is the correct one: May tells January that was told to "strugle with a man upon a tree" in order to heal January's eyes. ${ }^{102}$ Proserpina's gift of rhetoric decides this battle over language-who names the act, how it is named, and the punishment associated with it-in May's favor. The sex act between May and Damian is described crudely, as "Damyan / Gan pullen up the smok, and in he throng," and may seem to objectify May in the same way that she is objectified sexually by January. ${ }^{103}$ However, this scene "offers a strictly male perspective on what happens in the pear tree,"104 as the subsequent focus on January's sight demonstrates: "I saugh it with myne yen," January exclaims. That male vantage point, which seemingly objectifies May, obscures May's obvious agency in planning the tryst.

${ }^{100}$ Proserpina's reference to her hair as her locus of power may allude to the biblical story of Samson and Delilah (Judges 16). Proserpina's verbal power and Samson's physical strength both hinge on the preservation of their long hair; structurally, hair plays the same role in the potential to exercise power in both narratives.

${ }^{101}$ Merchant's Tale, 4.2312, 167.

${ }^{102}$ Ibid, 4.2372-78, 167.

${ }^{103}$ Ibid, 4.2352-53, 167.

${ }^{104}$ Eric Jager, The Tempter's Voice: Language and the Fall in Medieval Literature (Ithaca and London: Cornell U P, 1993), 289. 
For verraily he [Damian] knew al hire [May's] entente,

And every signe that she koude make,

Wel bet than Januarie, hir owene make,

For in a lettre she hadde toold hym al

Of this matere, how he werchen shal. ${ }^{105}$

Unlike May's marriage to January, or Proserpina's marriage to Pluto, May's relationship with Damian is consensual. She plans the encounter and explicitly directs Damian's behavior, avoiding the imbalanced power dynamics of her marriage to January. In May's deception of January, and in Proserpina's chiding of Pluto, The Merchant's Tale demonstrates how lying and scolding can insulate women from punishment.

Although May and Proserpina can be accused of duplicity, the narrative logic of the Merchant's Tale suggests that their tactics come in response to misogyny. May does, of course, cuckold her husband, and her speech allows her to get away with it. Her suggestion that in the coming days "ful many a sighte [may] yow bigile" indicates that she will not stop her relationship with Damian. ${ }^{106}$ Similarly, Proserpina's triumph over Pluto perhaps lends irony to her closing exclamation that she will no longer chide or "contrarie" Pluto. ${ }^{107}$ However, the audience is left to assume that there will be future arguments and disagreements between Proserpina and Pluto, just as we are left to assume that May will continue to deceive January. Proserpina, whose gift enables May's lies, can be accused of duplicity as well. But the unfairness of Pluto's attack on Proserpina's virtue, especially in light of Pluto's mythical and violent rape of Proserpina, complicates a reading of The Merchant's Tale as ultimately affirming depictions of women's speech as wicked. In short, Proserpina is acting in response to the misogynist tradition that depicts women as sinful blabbermouths. And the logic of the tale-that Proserpina's gift is given only after her rape and Pluto's misogynist outburstimplies that misogyny came first: that women chide, lie, and swear in response to misogynist men.

Those rhetorical tactics Proserpina uses to subvert Pluto's misogynist intent and that May uses to deceive January also characterize the Wife of Bath. The Wife of Bath describes how she uses "Deceite, wepyng, spynnyng" and "continueel murmur or grucchyng," which God gave "To wommen kyndely," to get what she wants from her

\footnotetext{
${ }^{105}$ The Merchant's Tale, 4.2212-15, 165.

${ }^{106} \mathrm{Ibid}, 4.2406,168$.

${ }^{107}$ Ibid, 4.2314-19, 167.
} 
husbands. ${ }^{108}$ Although the Wife credits God and not Proserpina, her tactics are a divinely inspired equivalent of Proserpina's gift. While she employs grumbling and complaining, chiding is the Wife's rhetorical tactic of choice- and the tactic to which her husbands most object. Chiding becomes a term around which male anxiety concerning women's speech revolves in the Canterbury Tales, for within Proserpina's theorization of rhetoric, scolding allows women to assert agency in their relationships with men. Male anxiety over women's speech manifests most explicitly in Jankyn's "book of wykked wives." The Wife's fifth husband, the combative clerk Jankyn, spends his evenings reading aloud from his "book of wykked wives," a collection of biblical stories that depict women (and their speech) as sinful and wicked. Jankyn's book equates chiding women with dangerous beasts, saying that "Bet is . . . thyn habitacioun / Be with a leon or a foul dragoun, / Than with a womman usynge for to chyde." ${ }^{109}$ In Jankyn's hands, the "book of wykked wives" represents church-sponsored misogyny by joining Jankyn (a clerk training for the clergy) with misogynist readings of the bible. This explicit conflation of misogynist discourse with religious authority causes the Wife of Bath to imagine chiding her husbands even in the presence of the Pope. The Wife would chide her first three husbands (whom she discusses as one entity):

For thogh the pope hadde seten hem biside,

I wolde nat spare hem at hir owene bord,

For, by my trouthe, I quitte hem word for word . . .

I broughte it so aboute by my wit

That they moste yeve it up, as for the beste,

Or elles hadde we nevere been in reste;

For thogh he looked as a wood leon,

Yet sholde he faille of his conclusion. ${ }^{110}$

In other words, the Wife has no problem arguing with her husbands, and she would chide them even in the company of the Pope. The Wife uses chiding in order for her husbands to "yeve it up," or to give upa phrase that Pluto repeats verbatim in response to Proserpina's chiding in the Merchant's Tale. ${ }^{111}$ As the Wife insists, her chiding cannot be regulated even by the presence of religious or social authorities; instead, she will "quitte," or take revenge on, every one of her husband's misogynist remarks. Her chiding, however, gives way to

\footnotetext{
${ }^{108}$ The Wife of Bath's Prologue, 3.401-06, 110.

${ }^{109}$ Ibid, 3.775-77, 115.

${ }^{110} \mathrm{Ibid}, 3.420-30,110$.

${ }^{111}$ The Merchant's Tale, 4.2312, 167.
} 
physically striking her husband and plucking three pages from his book. Enraged, Jankyn strikes her. Gourlay notes that the Wife of Bath is punished for her outward show of anger, "result[ing] in a beating that leaves her with a contrite husband, but also deaf in one ear." ${ }^{\prime 12}$ This domestic violence, however, falls within the realm of the physical, not the verbal. And as Proserpina claims, her gift of defensive rhetoric is calculated to ensure that no woman "shal dyen"that women will have rhetorical tactics to help avoid death at the hands of powerful, angry men. After this violence, the Wife of Bath claims that Jankyn attempted to murder her for her land and money. Jankyn apologizes and they were "acorded by us selven two." Through deftly maneuvering this volatile situation, she gains, as she claims, "governance of hous and lond, / And of his tonge, and of his hond also; / And made hym brenne his book anon right tho."113 Her speech, in other words, effectively leverages power from Jankyn. Although the Wife of Bath's "maistree" over her husband comes at a dire physical cost, the Wife of Bath's rhetoric-as Proserpina claims - ensures that she avoids the fate of a woman such as Phebus' wife of the Manciple's Tale, who is not afforded the ability to defend herself verbally before her husband kills her. ${ }^{114}$ The Wife of Bath is, of course, abused physically by her husband. But as Eric Jager argues, the Wife of Bath, like May, uses language to help level the gendered power differentials between husband and wife. ${ }^{115}$

\section{Rhetoric and Poetic: Then And Now}

Through highlighting the relationship between classroom rhetoric and Chaucer's poetics, I hope to argue for a return to a critical lens that reemphasizes the importance of rhetoric for understanding medieval literary texts. It was once commonplace for scholars of the Middle Ages to engage with rhetorical and literary theory. One need only look to the works of E. R. Curtius, Robert O. Payne, and Donald Howard to see the benefits of a critical apparatus that emphasizes the overlap between rhetoric and poetic. Recently, however, literature and rhetoric have separated into discrete disciplines, departments, and fields-and the dialogue between our journals, conferences, and faculties is diminishing. It may be time to return to an earlier type of scholarship that

\footnotetext{
${ }^{112}$ Gourlay, "Pugnacious," 142. See n. 83 above.

${ }^{113}$ The Wife of Bath's Prologue, 814-816, 116.

${ }^{114}$ The Manciple's Tale, 9.257-270, 285.

${ }^{115}$ Eric Jager, 296-97, citred in n. 104 above.
} 
emphasizes the rhetorical roots of textual and cultural analysis (a type of scholarship that Woods and Camargo typify), a return that also attends to the issues of gender, power, and politics ushered in by the postmodern critical movements. As the "received form of critical analysis all the way from ancient society to the eighteenth century," Terry Eagleton argues that a return to rhetoric as a critical lens can help us see texts as "forms of activity inseparable from the wider social relations between writers and readers, orators and audiences, and as largely unintelligible outside the social purposes and conditions in which they were embedded."116 Just as Chaucer's poetry allows readers to glimpse what women and men might have looked like in their domestic arguments and the power differentials that conditioned women's interactions with men, so too can rhetorical analysis reveal how medieval literature functioned as a site in which social, aesthetic, and rhetorical issues collided; that Chaucer's poetry is a "form of activity" that explores social problems and theorizes gendered rhetoric. This return to rhetoric can not only help us better understand the medieval period, but also open texts to new readings. ${ }^{117}$

${ }^{116}$ Terry Eagleton, Literary Theory, 2nd ed. (London: Blackwell, 2003), 179 (emphasis original).

${ }^{117}$ I would like to thank Marjorie Curry-Woods, Glynis Ridley, and Melissa Ianetta for their helpful advice and corrections on this essay. 